\title{
PENDIDIKAN KECAKAPAN HIDUP (LIFE SKILLS)
}

\section{Prof. Dr. Hj. Mulyani Sumantri, M.Sc.}

\begin{abstract}
:
Life skills adalah kemampuan atau kecakapan yang dimiliki seseorang untuk memecahkan problema hidup secara proaktif dan kreatif. Kecakapan hidup dapat berhubungan dengan kecakapan: mengenai diri, berfikir rasional, sosial, akademik, dan vokasional. Secara umum tujuan pembelajaran life skills adalah menyiapkan para siswa dengan pengetahuan, nilai-nilai dan keterampilan untuk memasuki dunia kerja dan kehidupan di masyarakat. Secara khusus life skills bertujuan untuk mengembangkan antara lain: kecakapan komunikasi, sikap dan prilaku yang sesuai dengan nilai-nilai di masyarakat, kemandirian, pengetahuan tentang sumberdaya alam, kemampuan pra-vokasional, dan vokasional, memecahkan masalah, dan pemanfaatan waktu senggang. Model pembelajaran yang dekat dengan pembentukan kecakapan hidup adalah model pembelajaran terpadu (integrated learning) dan model pembelajaran kontekstual (contextual teaching and learning). Model pendidikan realistik merupakan upaya mengatur pendidikan sesuai dengan kebutuhan nyata siswa di tengah masyarakat.
\end{abstract}

\section{Keywords :}

Life skills, model pembelajaran, dan pendidikan realistik

A. Kecakapan Hidup (Life Skills) Pada esensinya life skills adalah kemampuan siswa untuk memahami dirinya dan potensinya dalam kehidupan, antara lain mencakup penentuan tujuan, memecahkan masalah dan hidup bersama orang lain. Kemampuan tersebut akan membantunya untuk hidup dalam lingkungannya dengan sehat serta memiliki perilaku yang produktif. $\mathrm{Pe}$ nelitian ilmiah menunjukkan bahwa life skills education membantu siswa untuk melindungi dirinya dari berbagai bahaya, bukan hanya obat terlarang tetapi lebih dari itu untuk mengajarkan basic life skills kepada siswa untuk memasuki kehidupan sebagai orang dewasa dengan berhasil (Davis, 2000). 
Pengertian lain tentang kecakapan hidup, dapat diartikan sebagai suatu kecakapan yang dimiliki seseorang untuk mau dan berani menghadapi problema hidup dan kehidupan secara wajar tanpa merasa tertekan, secara proaktif dan kreatif mencari serta menemukan solusi sehingga akhirnya mampu mengatasinya.

Dalam hidup, di manapun dan kapanpun orang selalu menemui masalah yang harus dipecahkan. Kecakapan hidup dapat dipilah menjadi lima, yaitu:

1. Kecakapan mengenal diri (self awareness), yang juga sering disebut kemampuan personal (personal skills)

2. Kecakapan berpikir rasional (thinking skills)

3. Kecakapan sosial (social skills)

4. Kecakapan akademik (academic skills), dan

5. Kecakapan vokasional (vocational skills).

Kecakapan mengenal diri (self awareness) mencakup:

a. Penghayatan diri sebagai makhuk Tuhan Yang Maha Esa, anggota masyarakat dan warga negara;

b. Menyadari dan mensyukuri keebihan dan kekurangan yang dimiliki, sekaligus menjadikannya sebagai modal dalam meningkat- an dirinya sebagai individu yang bermanfaat bagi sendiri dan lingkungannya.

Kecakapan berpikir rasional (thinking skills) mencakup:

a. Kecakapan komunikasi dengan empati (communication skills),

b. Kecakapan bekerjasama (collaoaion skills).

Berempati, sikap penuh pengertian dan seni komunikasi dua arah, perlu ditekankan karena yang dimaksud berkomunikasi bukan sekedar menyampaikan pesan, tetapi isi dan sampainya pesan disertai dengan kesan baik akan menumbuhkan hubungan yang harmonis.

Bagi bangsa Indonesia yang bersifat religius, kecakapan hidup (life skills) di atas masih harus ditambah sebagai panduan, yaitu akhlaq. Artinya kesadaran diri, berpikir rasional, hubungan interpersonal, kecakapan akademik serta kecakapaan vokasional harus dijiwai oleh akhlaq mulia. Akhlaq harus menjadi kendali setiap tindakan seseorang. Karena itu kesadaran diri sebagai makhluk Tuhan harus mampu mengembangkan akhlaq mulia tersebut. Di sinilah pentingnya pembentukan jati diri dan kepribadian (character building) guna menumbuhkembangkan penghayatan nilai-nilai etika, sosial, dan religius 
yang merupakan bagian integral dari kualitas tindakan individu dalam pendidikan di semua jenis dan banyak hal dipengaruhi oleh kualitas jenjang. kematangan berbagai aspek pendukung tersebut di atas.

Kecakakapan akan diperlukan seserang untuk menghadapi problema bidang khusus terentu. Misalnya untuk mmecahkan masalah penjualan barang yang tidak laku, tentu diperlukan keterampilan pemasaran, dan seterusnya.

\section{B. Tujuan Pembelajaran Life Skills bagi Siswa}

Program life skills didesain agar bermanfaat bagi siswa, memberikan pengetahuan dan keterampilan yang diperlukan oleh siswa untuk meningkatkan tanggung jawabnya dan untuk

Kecakapan akademik (academic mengembangkan potensi sepenuhskills), atau kemampuan berpikir ilmiah (scientifice method) mecakup:

1. Identifikasi variabel

2. Merumuskan hipotesis

3. Melaksanakan penelitian.

nya. Tujuan umum pembelajaran life skills bagi siswa adalah untuk mengembangkan sikap, kemauan, kecakapan manajemen diri, kecakapan akademik, kecakapan sosial kemasyarakatan dan kecakapan vokasional

Kecakapan vokasional (vocational serta pengetahuan yang diperlukan skills), sering disebut keterampilan kejuruan, artinya keterampilan yang dikaitkan dengan bidang pekerjaan tertentu yang terdapat di masyarakat.

Perlu disadari bahwa di alam kehidupan nyata, antara general life skills (GLS) dan (specific life skills) atau SLS, antara kecakapan mengenai diri, kecakapan berpikir rasional, kecakapan sosial, kecakapan akademik, dan kecakapan vokasional tidak berfungsi secara terpisah-pisah, atau tidak terpisah secara eksklusif. Hal yang terjadi sebuah tindakan individu yang melibatkan aspek fisik, mental, untuk memasuki alam pekerjaan dan kehidupannya dalam masyarakat. Siswa diharapkan mampu mengembangkan kecakapan yang akan diperlukannya agar dapat berkiprah secara mandiri dalam masyarakat dan memiliki kemampuan sebaik mungkin. Tujuan khusus pembelajaran life skills adalah:

1. Menyajikan kecakapan berkomunikasi dengan menggunakan berbagai teknik yang memadai bagi siswa.

2. Mengembangkan sikap dan periaku yang sesuai dengan masyarakat masa kini dan memenuhi emosional dan intelektual. Derajat kebutuhan di masa datang. 
3. Mengembangkan kemampuan 3. Kehidupan mandiri membantu diri dan kecakapan 4. Kemampuan akademik hidup agar setiap siswa dapat 5. Kecakapan pra-vokasional dan mandiri. vokasional

4. Memperluas pengetahuan dan kesadaran siswa mengenai sumber-sumber dalam masyarakat 6. Pemanfaatan waktu luang dan rekreasi

5. Mengembangkan kecakapan akademik yang akan mendukung kemandirian setiap siswa.

7. Pendidikan jasmani

8. Pemecahan masalah

9. Kecakapan pribadi/sosial

10. Kecakapan bermasyarakat.

6. Mengembangkan kecakapan pravokasional dan vokasional dengan memfasilitasi latihan kerja dan pengalaman kerja di masyarakat.

\section{Pembelajaran Life Skills di Sekolah}

Pembelajaran life skills dimulai de-

7. Mengembangkan kecakapan untuk memanfaatkan waktu senggang dan melakukan rekreasi.

8. Mengembangkan kecakapan untuk memecahkan masalah untuk membantu siswa melakukan pengambilan keputusan masa kini dan di masa depan.

\section{Desain Program Life Skills}

Pembelajaran dalam program life skills dilaksanakan secara individual atau dalam kelompok kecil, dengan berlandaskan kebutuhan belajar setiap siswa. Pembelajaran yang dilaksanakan secara individual terutama bagi siswa yang mengalami kesulitan belajar.

ngan memperkaya setiap siswa tentang kesadaran dirinya (self awareness) membentuk citra diri yang positif dan memotivasi siswa untuk bertanggung jawab tentang kesehatan dan kebahagiaan dirinya.

Langkah selanjutnya adalah membimbing siswa untuk dapat berorientasi secara sehat dengan orang lain. Budi pekerti yang baik dibutuhkan untuk menghormati diri sendiri dan orang lain. Untuk memenuhi kebutuhan ini, pendidikan budi pekerti menjadi sangat penting untuk dilaksanakan di sekolah.

Fokus pembealajaran life skills adalah:

1. Komunikasi

2. membantu diri sendiri

Pembelajaran life skills menjanjikan cara yang terarah kepada guru dan orang tua agar mampu memberikan pengetahuan dan keterampilan kepada anak-anaknya. Program life skills terkait dengan semua aspek 
pengalaman yang terdapat di sekolah. Program ini digunakan oleh guru dan siswa untuk mengevaluasi kinerja (performance) mereka, baik secara individual maupun kelompok, serta memberikan pemahaman tentang perilaku sosial yang akan menunjang keberhasilan.

Mata pelajaran di sekolah adalah alat untuk mengembangkan potensi siswa sebagai bekal hidup agar pada saatnya dapat digunakan untuk mencari nafkah dan bermasyarakat. Bekal itu identik dengan pendidikan berorientasi kecakapan hidup (life skills), antara mata pelajaran life skills dengan kehidupan nyata terdapat hubungan yang erat.

Pemberian bekal bagi peserta didik yaitu apa yang dipelajari pada setiap mata pelajaran diharapkan dapat membentuk kecakapan hidup yang nantinya diperlukan pada saat yang bersangkutan memasuki kehidupan nyata di masyarakat.

Model pembelajaran terpadu (integrated learning) dan pembelajaran kontekstual (contextual teaching and learning) atau CTL merupakan model pembelajaran yang mengarah pada pembentukan kecakapan hidup.

Model pendidikan realistik (realistic education) yang kini sedang berkembang, juga merupakan upaya mengatur antara pendidikan sesuai kebutuhan nyata siswa, agar hasilnya dapat diterapkan guna memecahkan dan mengatasi problema hidup yang akan dihadapi. Untuk mencapai kecakapan hidup memerlukan model evaluasi otentik (authentic evaluation), yaitu evaluasi dalam bentuk perilaku siswa dalam menerapkan apa yang dipelajari dalam kehidupan nyata. Paling tidak dalam bentuk shadow authentic, yaitu bentuk tugas proyek/kegiatan untuk memecahkan masalah yang memang terjadi di masyarakat.

\section{LITERATUR}

Depdiknas. (2003). Pendekatan Kontekstual (Contextual Teaching and Learning) (CTL). Jakarta.

IRSA. (2003). Applied Life Skills: Modul, www://Refugeesusa.org.

Kent Davis. (2003). Life Skills for Kids. News.www//lifeskills4kids. com

Parks Victoria. (2003). Personal Development. Modul. Australia.

Sida. (2001). Life Skills Approach to Child and Adolesance. Healhtly Human Development, WK. Kellog foundation. Swedia.

Unicef. (2003). Life Skills Principles in formal and Nonformal Setting. Teacher Manual. New York. 